\title{
Cost Optimization in Building Construction Projects with Special Reference to Kathmandu Valley of Nepal
}

\author{
Surendra Kumar Karn ", Khet Raj Dahal \\ Email address: \\ karnasurendra@gmail.com (S. K. Karn), krdahal@liast.edu.np (K. R. Dahal) \\ ${ }^{*}$ Corresponding author
}

Department of Construction Engineering and Management, Lumbini International Academy of Science and Technology, Lalitpur, Nepal

\section{To cite this article:}

Surendra Kumar Karn, Khet Raj Dahal. Cost Optimization in Building Construction Projects with Special Reference to Kathmandu Valley of Nepal. American Journal of Science, Engineering and Technology. Vol. 6, No. 1, 2021, pp. 8-19. doi: 10.11648/j.ajset.20210601.12

Received: January 4, 2021; Accepted: January 12, 2021; Published: April 26, 2021

\begin{abstract}
Cost optimization is a process that should be carried out throughout the construction period to ensure that the cost of the project is within an allotted budget. Time and cost are the two most significant factors in any construction project. Cost increases with the time of construction. The objective of this study was to find out the factors that contribute to the optimization of construction costs in building construction projects in Nepal. The study was conducted during the period from April 2019 to September 2020. Field observation, in-depth interviews, focus group discussions and questionnaire surveys were the major tools for the investigation of this study. The findings were analyzed in nine categories: project related factors, design related factors, owner related factors, consultant related factors, contractor related factors, material related factors, labor related factors, equipment related factors, and external factors. The study found some key factors related to time and cost overrun, optimizing cost of construction and the strategies to optimize project costs. The most important strategy to optimize the construction cost are effective cost planning and control, development of proper monitoring and tracking system, sound working environment, recording daily work progress, using time cost trade off, follow plan-do-check-act quality policy, hire skilled labor and effective supervision. The study suggests that constructability and value engineering principles should be adopted in construction projects.
\end{abstract}

Keywords: Cost Optimization, Time Overrun, Cost Overrun, Constructability and Value Engineering

\section{Introduction}

Optimization is defined as value achievement with minimum cost. It focuses on cost reduction, assurance of quality, value enhancement and value maximization. Cost optimization offers substantial cost saving to companies through an improvement in their bottom line, efficient use of resources, reduction in overhead and enhancing employee productivity [1].

The construction industry is complex because it contains a large number of parties such as clients, contractors, consultants, stakeholders, shareholders, regulators and others [2]. The construction industry is one of the largest businesses in the world. Growth in this business in fact is an indicator of the development of a country. In a developing country, construction industry is significant as it provides employment as well as infrastructure. The construction industry contributes to the development of infrastructure, sanctuary, hospitals, schools, townships, offices, houses, water supply, sewerage, drainage, highways, roads, ports, railways, airports, power systems, irrigation, and telecommunications [3]. Further, it deals with all economic activities directed to the creation, renovation, repair or extension of fixed assets in the form of buildings, land improvements of an engineering nature. It provides a growth impetus to other sectors through backward and forward linkages.

Nepal Construction Industry is fast growing service industry in Nepal. Nepalese Construction Industry contributes around 10 to 11 percentage to the GDP and it uses around 35 percent of government budget [4]. Similarly, it is estimated that this sector is creating employment opportunities to about one million people, which means that it is the second largest source of employment in the country after agriculture. The share of Nepalese construction sector to 
GDP is expected to remain at 7.6 percentage in the year FY 2017/18 [5]. Similarly, about 60 percentage of the nation's development budget is spent through the use of contractors [6].

Most of the building construction projects are facing the problem of time and cost overruns. The major factors that impact cost of construction are material, labour, equipment, overhead and profit [7]. Delay in the intended completion date causes substantial financial burden to the stakeholders of this industry. In this context, Nepalese construction industry is also not an exception [8].

Time, money and resources are the major constraints in any construction. There exists high competition in the market in the field of building construction. Execution period is always crucial for any building project to be successful. It is necessary to expedite site activities and lower the associated expenses. Effective tools may be required for optimizing construction activities and improving the performance. Without proper knowledge of construction system and technology, construction process becomes costly and time consuming [9].

In order to control cost, scheduling and resources, sound construction management is essential. There are some traditional methods for effective project management including either Critical Path Method (CPM) or the Program Evaluation and Review Technique (PERT) combined with trial and error procedure. Some Software is also being used for effective scheduling of projects in construction management $[10,11]$.

The cost optimization is a process that should be carried out throughout the construction period to ensure that the cost of the building is kept within the estimated cost limits [12]. Globally, the construction industry faces the phenomenon of delays [13] and such delays are considered to be most recurring issues in the construction sector [14].

Poor planning, delays in deliveries, wastage of material, over budgeting, unexpected weather changes, lapse in management and control, loss of material, poor communication are some of the important factors responsible for cost and time overruns which lead to conflicts in any project [15], and this applies in the Nepalese context too. Thus, there is a great need to identify the methods for cost reduction or cost control. This study is focused on this problem and it is the main objective of the exploration in this area in the context of Nepal.

\section{Literature Review}

Cost optimization of a project ensures that a company makes substantial profits and the quality of work is satisfactory. [16]. Cost effectiveness is achieved through the following four ways: replacing conventional materials with alternative materials, good construction skills, proper building design, and proper planning and management of construction. According to $\mathrm{Ng}$ and Zhang, time and cost are the most important factors in every construction project, both client and contractors strive to optimize the project duration and cost concurrently [17]. Furthermore, crashing the activities, mathematical programming model, and linear programming model are used to optimize time and cost of the project.

Kashid and Jamgade stated that time factors include: construction activities to be done simultaneously, use of available local resources, proper selection of suppliers, use of multi skilled labour, use of new equipment for high efficiency and greater production, proper planning and scheduling. Cost factors are: use of alternate materials, cost effective construction materials, low cost materials, local materials; use of multi- skilled labour so that wastage should be minimum, use of resources for more efficiency and quality minimize rework and defective works and, proper selection of the supplier [18].

Multi skilling as a workforce strategy can be facilitated to reduce indirect labor costs, improve productivity, and reduce turnover. A multi skilled workforce is one in which the workers possess a range of skills that allow them to participate in more than one work process [19]. Precast concrete was found to be $22.31 \%$ cheaper than the cast-in situ concrete for large scale production [20]. Precast concrete construction reduces life cycle cost as well as wastage and increases speed of construction without compromising quality and strength [21].

The use of arch foundation which saves foundation expenses up to $40 \%$. Replacement of plinth slab by brick on edge can save $35-50 \%$ plinth cost. The use of rat-trap bond wall achieves the same strength as conventional $250 \mathrm{~mm}$ wall but requires $20 \%$ less bricks. Replacement of wooden frames by concrete or steel frames can be done for achieving cost reduction up to $40 \%$. Conventional RCC lintels cost $30-40 \%$ higher than brick arch lintels which can be used for smaller spans and for roofing, the use of filler slabs which is about $23 \%$ less costly than conventional slab [22].

According to Mishra and Bhandari, project performance is not satisfactory in terms of time in Nepal [23]. Maskey and Mishra found that time spent by skilled and unskilled labors in productive work were $56.92 \%$ and $55.74 \%$ respectively [24]. Labor productivity must be improved to reduce the cost. As per Chiluwal and Mishra, a good performance of any construction projects refers that it is free from defects, right things at right time and the continuous improvement of the project [25]. The shortcomings in performance are costly and often lead to disputes, claims and affect the development of the construction industry. Successful performance is achieved through sound environment of construction organization. Even if various techniques for optimization and project control software are available, many construction projects still fail to achieve their cost and time objectives. The basic scheduling techniques commonly used in practice include the Critical Path Method (CPM) and Program Evaluation Review Technique (PERT) [26, 27].

A waste hierarchy has been widely adopted as a guide for construction managers, in line with the principles of sustainable construction. Waste hierarchy is to reduce the generation of waste, to re-use of waste, recycling, 
composting or energy recovery from waste. Waste to dispose of safely if the above is found not applicable [28].

As per Wan Michelle, the construction sector is a basic industry on which the development of the country depends to a great extent, the growth of the construction companies is determined by the quality of the companies and their capability. Eight strategies can be used as value analysis for cost reduction, purchase products in bulk and with less packaging, quality control, local vendors, and partnership with major vendors, E-procurement, use better technology, and economic order quantity [29].

Constructability, simply, is the ability to construct efficiently and easily. Primary objective is to maximize efficiency, minimize waste, and complete construction projects on or ahead of schedule with collective knowledge and experience. Checklist approach is used for measuring constructability and getting major benefits: on- time completion, within budget, eliminate all types of errors, meet building standard codes, and ensure excellent construction [30]. Constructability of a design as the greatest level of ease to builder who arranges the raw materials of the construction process (labour, production, equipment, tools, materials and installed equipment) to complete the project in a timely and economic manner" [31].

A system of thinking based on the function of recognizing and reducing all unwanted costs with maintaining all types of quality in any industry, construction or services is called Value analysis [32]. "Value engineering is a tested management technique by means of a systematized approach searching for the best functional balance between the cost, reliability, and performance of a product or project" [33].

As per Abidin and Pasquire. Value engineering can save up to 10 to 15 percent of the total cost of the project [34].

Value Engineering strives to search for the most significant goals which are time and cost saving, quality improvement, mitigating unessential resource waste, accurate decisionmaking, and teamwork enhancement, without letting go of the performance enhancement factor [35]. Generally, cost reduction of $15 \%$ to $40 \%$ can be achieved if $\mathrm{VM}$ is applied [36]. As per Rane, the construction cost is reduced by $3.90 \%$ in case of M 25 concrete if $50 \%$ crushed sand is used instead of river sand whereas in case of reinforcement $(16-25 \mathrm{~mm})$, cost is reduced by $51.81 \%$ if couplers are used in place of lapping [37].

\section{Method of Study}

Tools used: Field observation, in depth interviews, focus group discussions and questionnaire surveys were the major tools used in this study.

Period of study: The study was conducted during the period from April 2019 to September 2020.

Data analysis and presentation: The data were analyzed using excel sheet and presented in pie chart, bar charts and tables. Relative importance index (RII) method was used to compare the statements obtained from the respondents.

Sample Size: Using purposive and convenience sampling method, a total number of 72 respondents were chosen for this study.

Study area: For case study purposes, six-building construction projects were selected and in-depth interview was conducted among the project managers and senior site engineers from both owner and contractors of the building construction projects. Out of the six building construction projects under case study, two projects are completed and are fully in operation whereas one project is almost completed and partly in operation, remaining three projects are under construction phase. The study area is shown in figure (Figure 1) and the building construction projects selected for case study are listed in table (Table 1).

\section{Results and Discussion}

\subsection{Respondents Category Based on Project Size in Terms of Budget}

Respondents are categorized into 4 groups based on the size of project involved during their professional carrier, in Nepalese currency. Among 72 respondents, 17\% have involved in less than 500 million, 30\% have $(0.5-1.0)$ billion, $42 \%$ have (1.0-5.0) billion, $11 \%$ have more than 5 billion presented in figure (Figure 2).

Table 1. List of case study building construction projects.

\begin{tabular}{|c|c|c|c|c|c|c|}
\hline \multirow{2}{*}{ S. No. } & \multirow{2}{*}{$\begin{array}{l}\text { Name of Building } \\
\text { Construction Projects }\end{array}$} & \multirow{2}{*}{ Category } & \multirow{2}{*}{ Location of Project } & \multicolumn{3}{|c|}{ Location in coordinates } \\
\hline & & & & Latitude & Longitude & Altitude from MSLevel \\
\hline 1.0 & Hyatt Place Kathmandu & 5 Star hotel (156 bedrooms) & Tahachal, Kathmandu & $85.2898^{\circ} \mathrm{E}$ & $27.6994^{\circ} \mathrm{N}$ & 1300.000 \\
\hline 2.0 & Marriott, Naxal & 5 Star hotel (214 bedrooms) & Thamel, Kathmandu & $85.3242^{\circ} \mathrm{E}$ & $27.7130^{\circ} \mathrm{N}$ & 1317.000 \\
\hline 3.0 & $\begin{array}{l}\text { Nepal Business Trade } \\
\text { Centre }\end{array}$ & $\begin{array}{l}\text { Wholesale market ( } 950 \\
\text { shops, } 350 \text { stores) }\end{array}$ & Khasibazar, Kathmandu & $85.2859^{\circ} \mathrm{E}$ & $27.6887^{\circ} \mathrm{N}$ & 1301.000 \\
\hline 4.0 & Soalteecity Project & $\begin{array}{l}\text { Housing ( } 20 \text { nos bungalows } \\
\text { and } 310 \text { nos apartments) }\end{array}$ & Rabibhawan, Kathmandu & $85.2902^{\circ} \mathrm{E}$ & $27.6955^{\circ} \mathrm{N}$ & 1308.000 \\
\hline 5.0 & The Villa, CG & Bungalows & Sunakothi, Lalitpur & $85.3177^{\circ} \mathrm{E}$ & $27.6226^{\circ} \mathrm{N}$ & 1438.000 \\
\hline 6.0 & Merocity Apartment Project & Apartments- 280 flats & Harisidhhi, Lalitpur & $85.3355^{\circ} \mathrm{E}$ & $27.6468^{\circ} \mathrm{N}$ & 1311.000 \\
\hline
\end{tabular}

Source: Field survey, 2020 


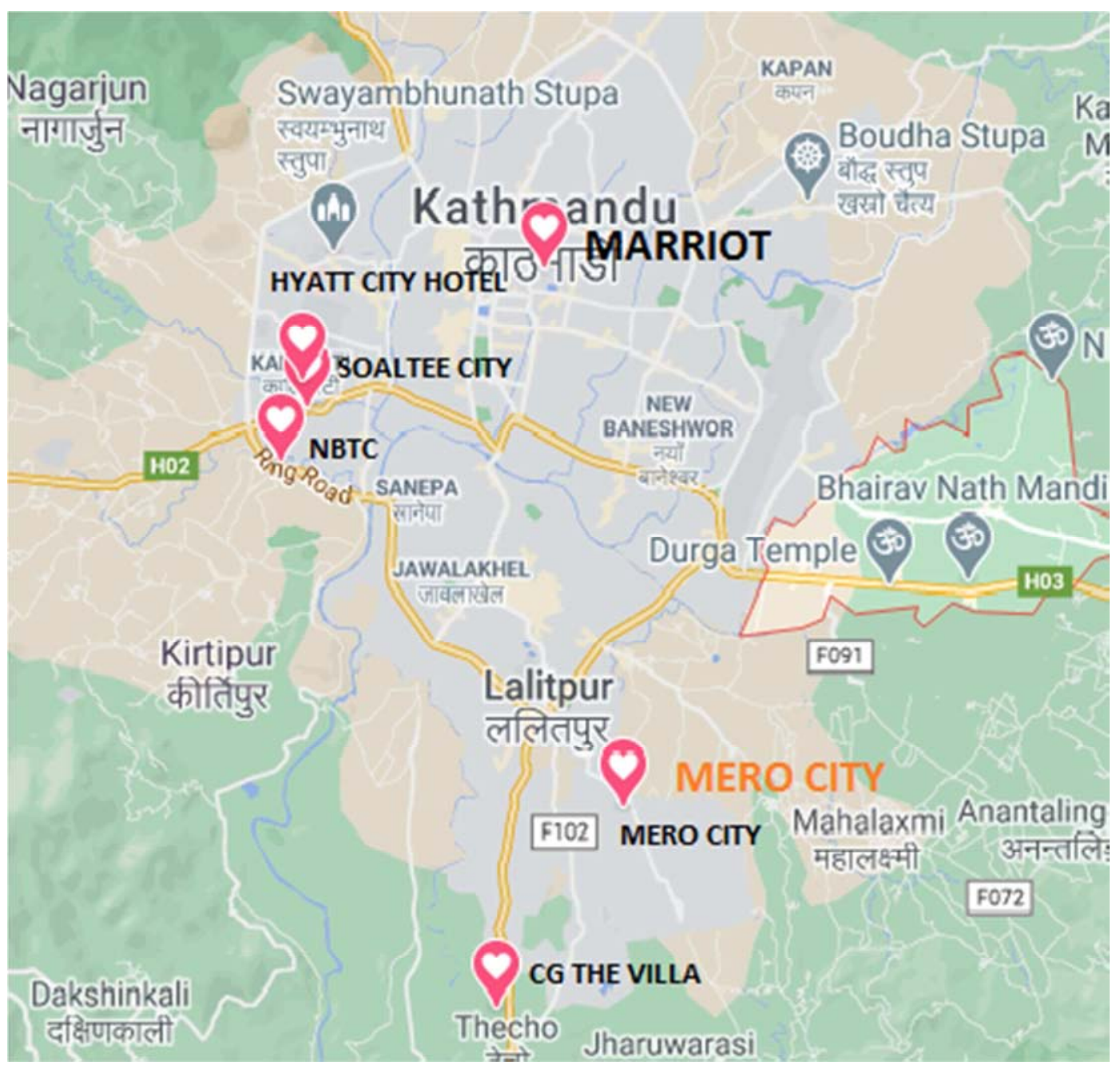

Figure. 1. Map of study area (Source: Google.com, 2020).

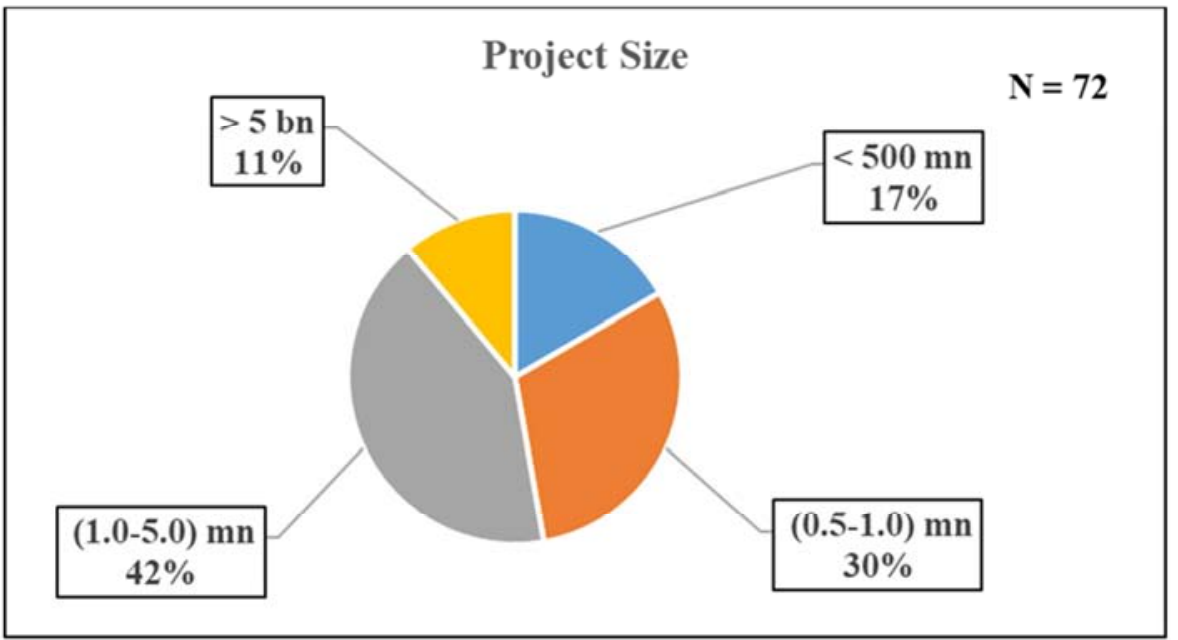

Figure 2. Project Size involved by respondent (Field Survey, 2020).

\subsection{Respondents Category Based on Their Designation}

Respondents are categorized based on their position in the organization, shown in figure (Figure 3). Out of 72 respondents, $25(35 \%)$ are project managers and $11(15 \%)$ are site engineers. 


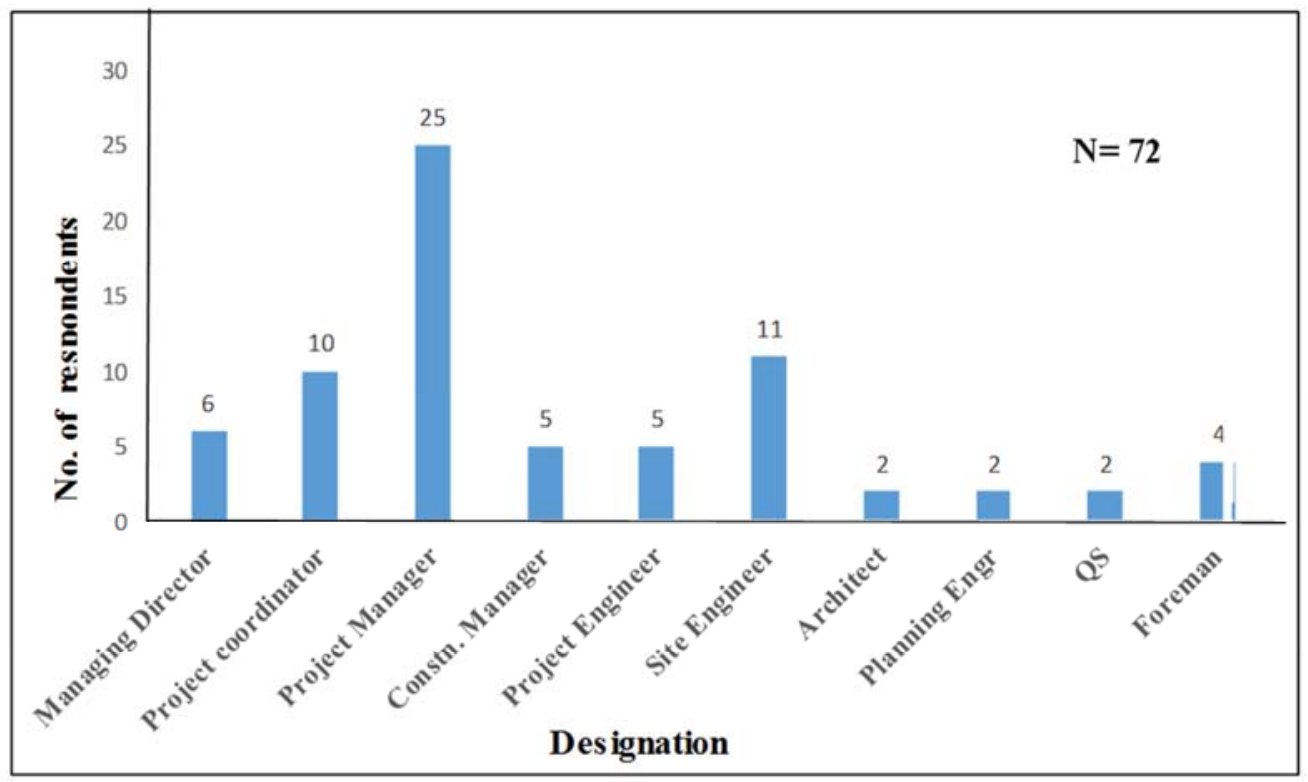

Figure 3. Designation of respondents (Field Survey, 2020).

\subsection{Reliability or Consistency Test Result}

Reliability or consistency test for questionnaire for factors contributing to optimize cost in building construction was conducted using Cronbach's alpha method and found value of alpha, $\alpha=0.955$ which is $>0.7$. This shows that the questionnaire is reliable and there exists internal consistency of data. The output of reliability test performed in SPSS v24 is presented in table (Tables 2, 3).

Reliability

Scale: ALL VARIABLES

Table 2. Case Processing Summary.

\begin{tabular}{llll}
\hline & & $\mathbf{N}$ & $\mathbf{\%}$ \\
\hline \multirow{3}{*}{ Cases } & Valid & 72 & 100.0 \\
& Excluded & 0 & .0 \\
& Total & 72 & 100.0 \\
\hline
\end{tabular}

a. List wise deletion based on all variables in the procedure.

Table 3: Reliability Statistics

\begin{tabular}{lll}
\hline $\begin{array}{l}\text { Cronbach's } \\
\text { Alpha }\end{array}$ & $\begin{array}{l}\text { Cronbach's Alpha based on } \\
\text { Standard Items }\end{array}$ & Number of items, N \\
\hline .924 & .927 & 45 \\
\hline
\end{tabular}

\subsection{Correlation Test Result for Factors to Optimize Construction Cost}

Spearman's rank correlation coefficient was determined using SPSS v24 to measure the degree of association associated with importance ranking of each two parties for factors contributing to optimize the construction cost while ignoring the ranking of the third party. The result shows that there is highest degree of association between owner and contractor $(99.5 \%)$ in comparison to other two groups. The relative agreement between each two groups is presented in table (Table 4).
Table 4. Spearman's rank correlation coefficient ( $\rho$ ) in SPSS.

Nonparametric Correlations

\section{Correlations}

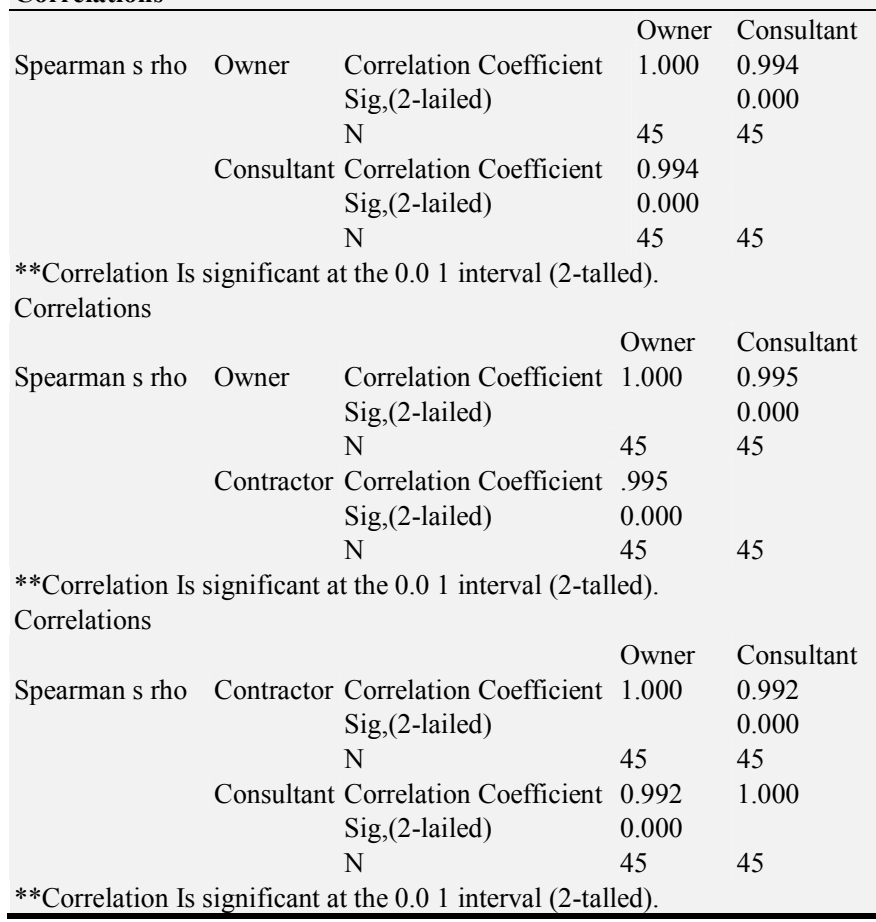

\subsection{Factors Contributing to Optimize the Cost in Building} Construction

A total of 45 factors (denoted by F) were categorized under nine different major groups. The identification and evaluation of these factors were carried out through secondary and primary data collection methods respectively and also validated through statistical methods. The major nine groups are: project related factors, design related factors, owner related factors, consultant related factors, contractor related 
factors, material related factors, labour related factors and equipment related factors, and external factors. The RII of each cost optimization factors were found out in these nine separate groups based on the views of the three types of respondents (Owner, Consultant and contractor's representatives). Subsequently, based on RII value so obtained, ranking of all the attributes was done based on combined views of each group of respondents. Finally, out of total 45 attributes, top ten most significant factors to optimize the construction cost were identified based on combined view of the respondents which is presented in Figure (Figure 4).

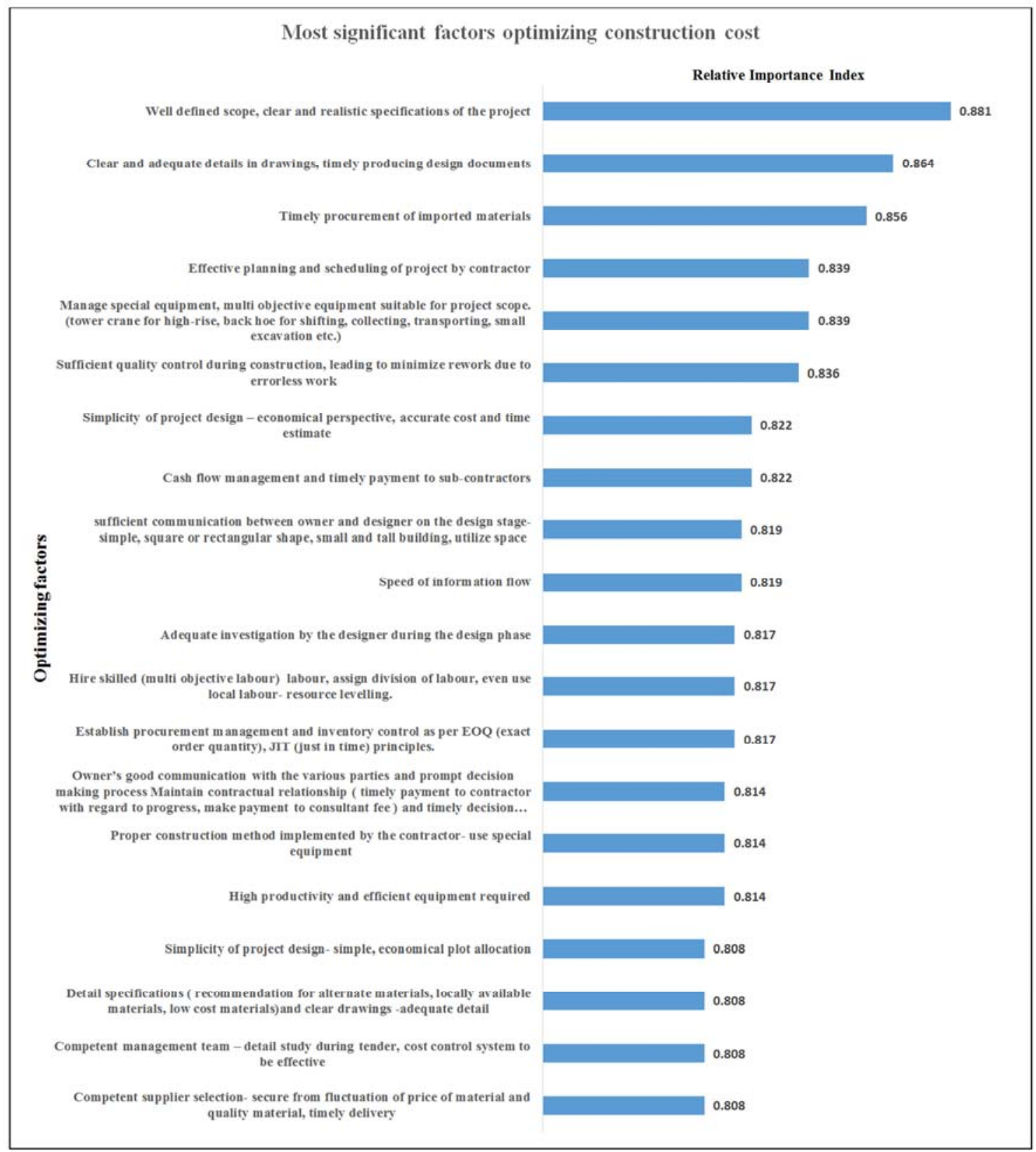

Figure 1. Factors contributing to optimize the construction cost (based on questionnaire survey).

\subsection{Problems that Can Lead to Cost Overrun of Project}

A total of six problems that can lead to cost overrun of project denoted by "P" were identified and respondents" views were collected in 5-point scale. Relative importance of the impact of delays was found out by using RII methods. The ranking of problems that can lead to cost overrun of project is presented in figure (Figure 5). As per combined views, "Delay caused by owner and his agent "is ranked as the first and "Quantity under estimation" is ranked as second. As regards the third in the ranking of combined view, it is "Design Change" which is agreed by all in the same position.

\subsection{Strategy to Optimize the Construction Cost}

A total of thirty factors for optimizing the construction cost (denoted by S) relevant to this study were identified through review of previous studies. Relative importance of the 
strategy factors was found out by using RII methods. The ranking of the factors optimizing the construction cost is presented in figure (Figure 6) in decreasing order of relative importance index and out of which thirty factors ranging from RII (0.867) to RII (0.758) having ranking 1 to 21 .

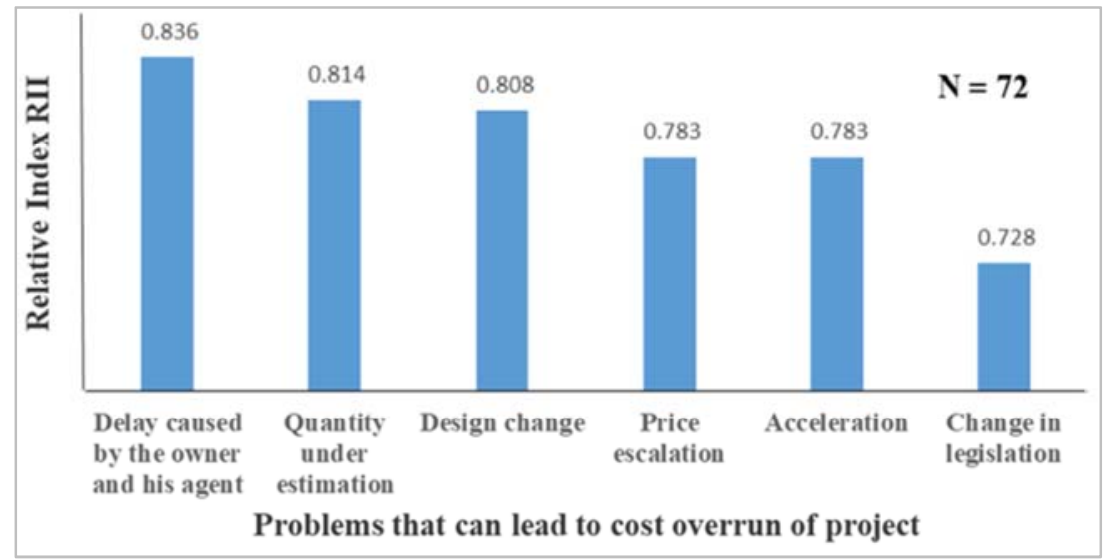

Figure 5. Problems that can lead to overrun of project (based on questionnaire survey).

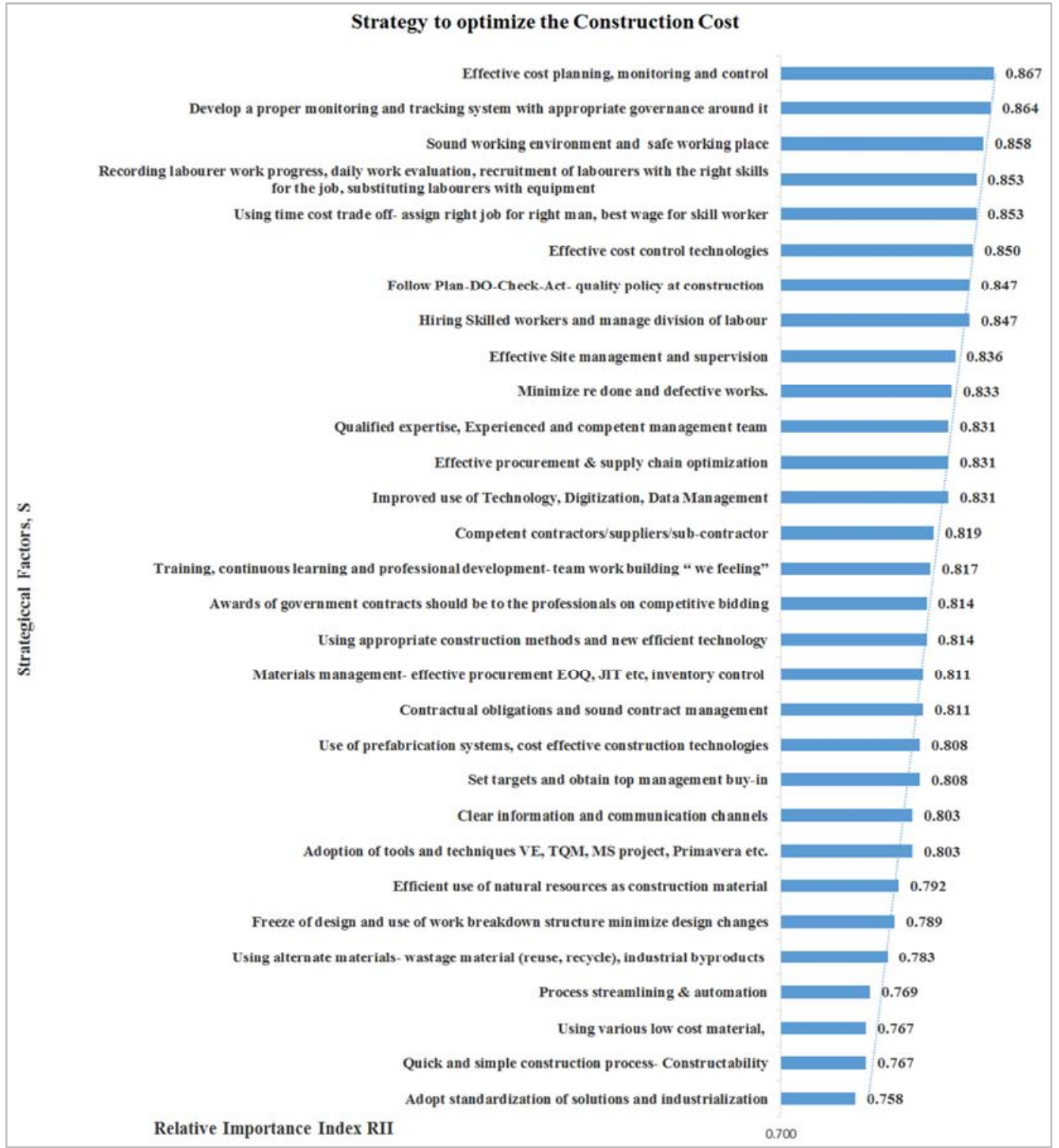

Figure 6. Strategy to optimize the construction cost (based on questionnaire survey). 


\subsection{Findings from in-Depth Interview}

The data based on closed ended questionnaire received during in-depth interview from the respondents are presented in Figures (Figures 7, 8, 9).

\subsubsection{Percentage of Cost Overrun Encountered}

All the respondents encountered cost overrun in their projects. Out of total 63 respondents, 23 reported 0-10\%, 18 reported $11-20 \%$ delays while 12 reported $21-30 \%$ delays is presented in figure (Figure 7 ).

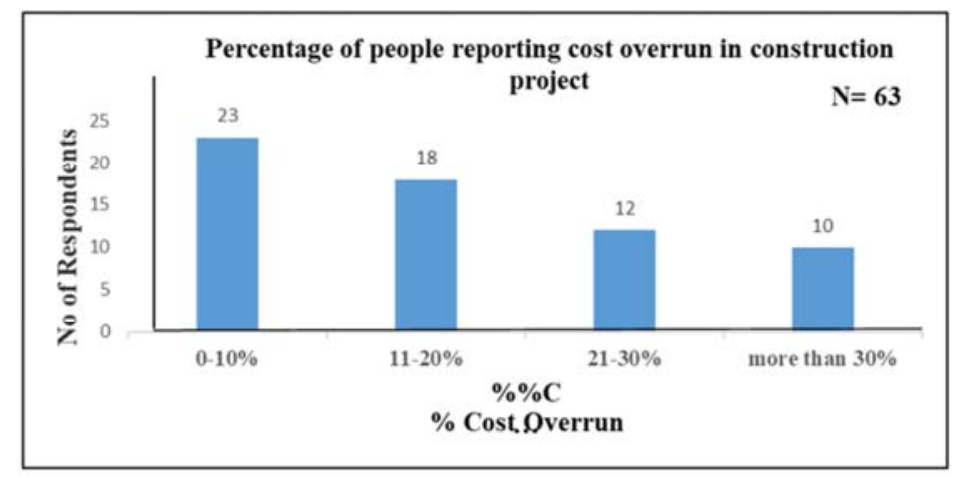

Figure 7. Percentage of cost overrun (based on in-depth interview).

\subsubsection{Percentage of time Overrun Encountered}

All the respondents encountered delays in their projects. Out of total 61 respondents, 24 reported 11-20\% delays while 16 reported more than $30 \%$ delays is presented in figure (Figure 8 ).

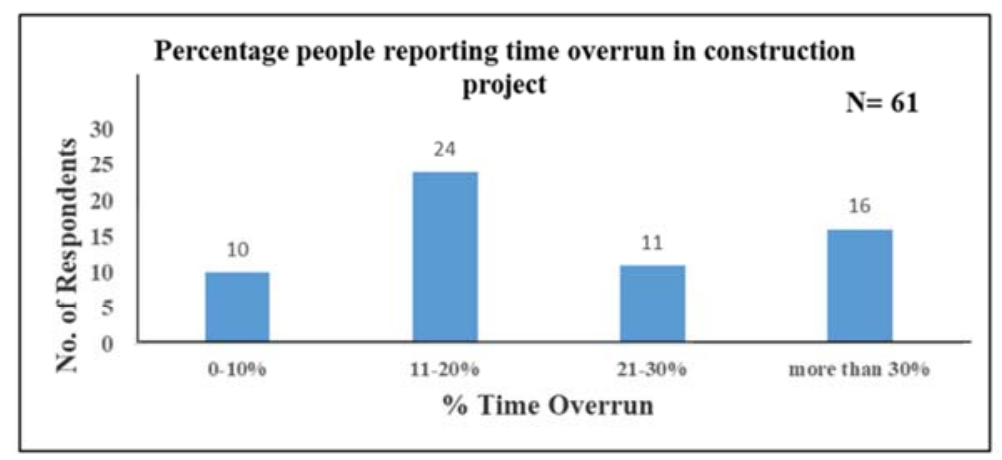

Figure 8. Percentage of time overrun (based on in-depth interview).

\subsubsection{Use of Planning and Scheduling Software}

Microsoft project and Primavera are two software which are widely used for planning and scheduling purposes. Out of 63 respondents, 38 (60\% of total) agreed that "Microsoft project" is being preferred by their organizations is presented in figure (Figure 9).

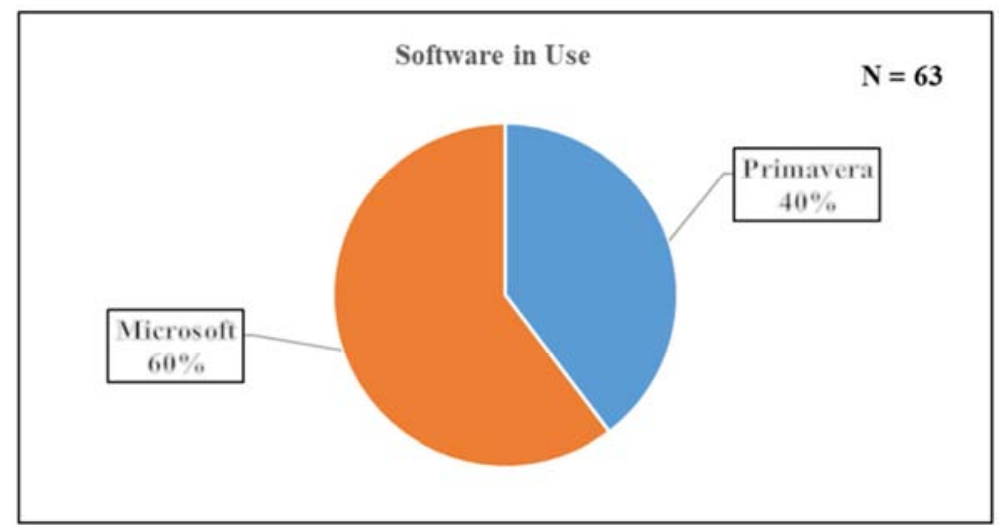

Figure 9. Planning Software in use (based on in-depth interview). 
Table 5. Major factors contributing to optimize the cost in building construction (based on Case study)

\begin{tabular}{|c|c|}
\hline Prevailing factors & Projects \\
\hline \multicolumn{2}{|l|}{ Project related factors } \\
\hline Improper selection of contractor having inexperience similar to nature of project & Soalteecity, Merocity, \\
\hline Labour contract difficult to manage $\mathrm{OH}$ caused improper supervision & Soalteecity, Merocity \\
\hline \multicolumn{2}{|l|}{ Design related factors } \\
\hline Inadequate investigation by designer & NBTC, Soalteecity, Merocity \\
\hline Unclear project specifications and bill of quantities & Soalteecity, Merocity, \\
\hline Incomplete design drawing and it to be revised & Merocity \\
\hline \multicolumn{2}{|l|}{ Owner related factors } \\
\hline Unrealistic Project duration & Hyatt Place, Soalteecity, Merocity \\
\hline Cash Flow problems & Hyatt Place, Soalteecity, Merocity \\
\hline Decision making problems for imported materials & SG villa, Soalteecity, Merocity, NBTC \\
\hline Material approvals & Hyatt place, NBTC, Soalteecity, SG villa \\
\hline Design Change & Hyatt place, Soalteecity, Merocity \\
\hline Contractual Relationship- not maintained & Soalteecity, Merocity, SG villa \\
\hline \multicolumn{2}{|l|}{ Consultant related factors } \\
\hline Underestimation of Budget & Hyatt Place, Soalteecity, Merocity \\
\hline Inconsistency in drawings and inadequate detail & Hyatt Place, Soalteecity, Merocity \\
\hline Lack of coordination between designers & Hyatt Place, Soalteecity, Merocity \\
\hline PMC Contract & NBTC \\
\hline \multicolumn{2}{|l|}{ Contractor related factors } \\
\hline Poor financial status & Hyatt Place, Marriot, SG villa, NBTC, Soalteecity, Merocity \\
\hline Delay in shop drawing and material submission & Hyatt Place, SG villa, Soalteecity, Merocity \\
\hline Lack of communication \& coordination & Hyatt Place, Marriot, Soalteecity, Merocity \\
\hline Improper planning \& scheduling & Marriot, NBTC, Soalteecity, Merocity \\
\hline Lack of competent management team & Soalteecity, Merocity \\
\hline \multicolumn{2}{|l|}{ Material related factors causing delays } \\
\hline Delay in Procurement \& Logistics & Hyatt place, Marriot, Soalteecity, Merocity, \\
\hline Scarcity of construction materials & Common to all \\
\hline Space limitation for material storage & Common to all \\
\hline Lack of procurement management and inventory control & Soalteecity, Merocity, \\
\hline \multicolumn{2}{|l|}{ Labour related factors } \\
\hline Lack of adequate and skilled manpower & Common to all \\
\hline Lack of finishing manpower & Common to all \\
\hline \multicolumn{2}{|l|}{ Equipment related factors } \\
\hline Lack of proper equipment, tower crane, transporting equipment & Hyatt Place, Marriot, Soalteecity, Merocity \\
\hline Space for heavy vehicle entry & Soalteecity \\
\hline Lack of mechanics for repair and maintenance of equipment & Marriot, Soalteecity, Merocity \\
\hline \multicolumn{2}{|l|}{ External factors causing delays } \\
\hline Effect of sub surface condition & Hyatt Place, Soalteecity, Merocity, NBTC, SG Villa \\
\hline Traffic restriction due to site location & Hyatt Place, Soalteecity, Marriot \\
\hline Custom issues & Hyatt Place, Soalteecity, Merocity \\
\hline Accident during construction & Hyatt Place, Merocity \\
\hline Neighbors problems during work execution & Hyatt Place, NBTC, Soalteecity, SG Villa \\
\hline Force Majeure (April 2015 Earthquake) & NBTC, Soalteecity, Merocity \\
\hline Political Instability (Border blockade) & NBTC, Soalteecity, Merocity \\
\hline Flood & NBTC, Merocity \\
\hline
\end{tabular}

\subsection{Findings from Case Study Projects}

All the building construction projects under the case study experienced time overrun and cost overrun. Time overrun was found ranging from 12-19 months whereas cost overrun was found ranging from $5 \mathrm{Cr}$. to $40 \mathrm{Cr}$. NPR $(160 \mathrm{NPR}=1 \$)$. Merocity experienced the highest time overrun while Hyatt city hotel experienced highest cost overrun. Among the six building construction projects, Nepal Business Trade Centre (NBTC) experienced $54 \mathrm{Cr}$. NPR cost saving due to optimization of construction cost having project management consultant (PMC) played great role.

The findings are summarized in figures (Figures 10 and 11). 


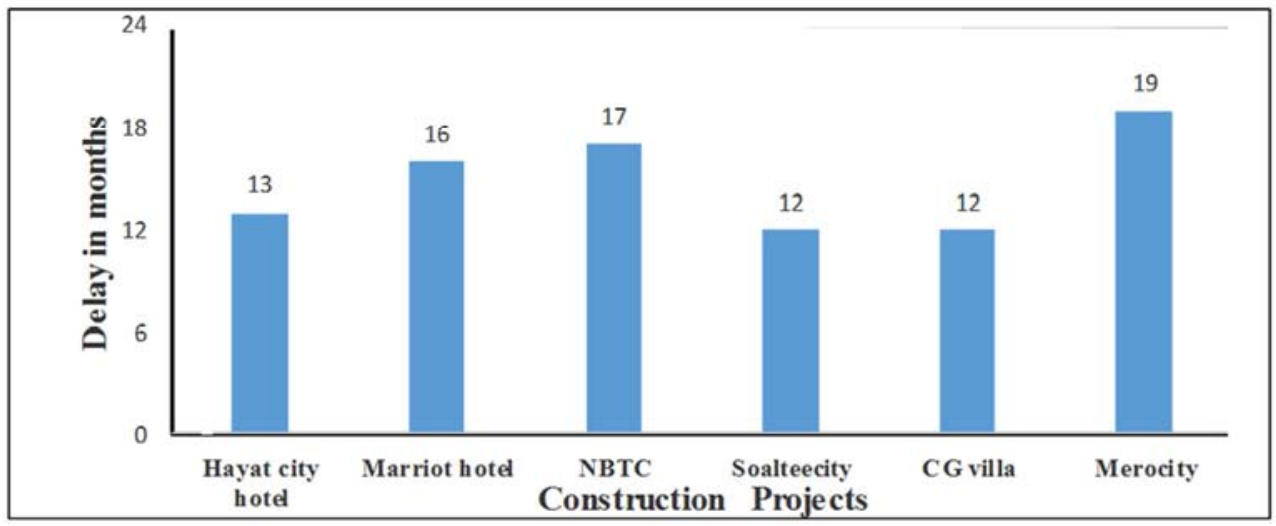

Figure 10. Time overrun observed in Building construction projects (based on Case Study).

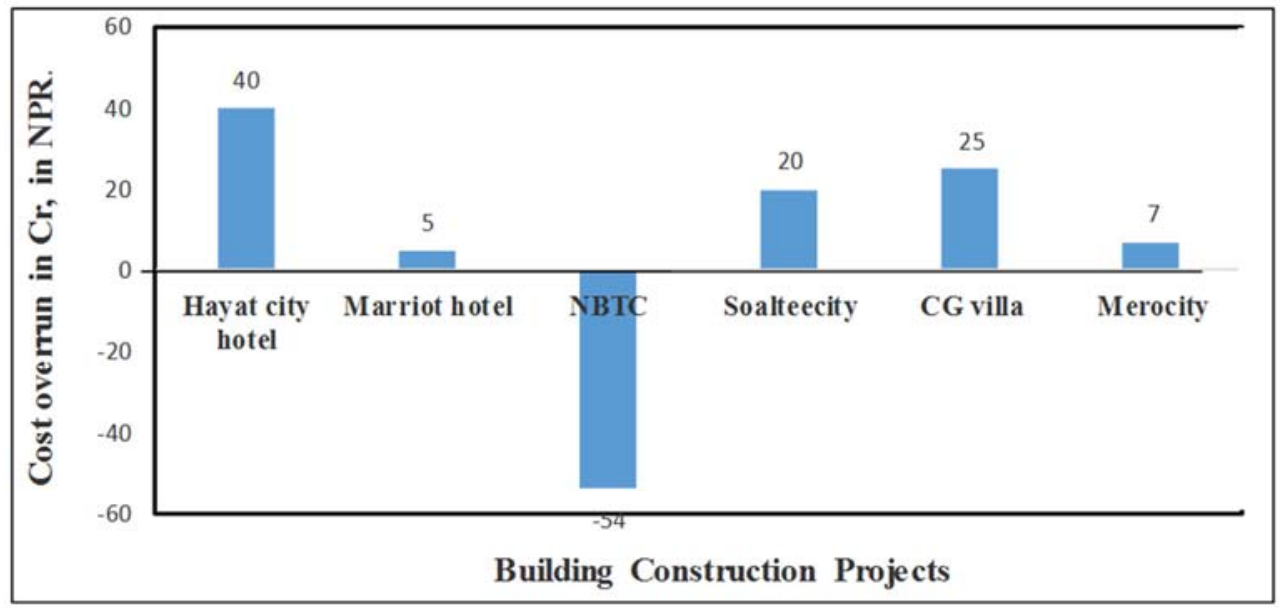

Figure 11. Cost overrun observed in Hotel projects (based on Case Study).

\section{10. Discussions}

The previous studies conducted by the researchers Savithra and Amutha (2019), Kashid and Jamgade (2019), Gomar et al. (2002), Asamoah et. al. (2016), Rajguru and Mahatme (2015), Taur and Devi (2009), Samuel (2015), Mishra and Bhandari (2018), Maskey and Mishra (2018), Wan Michelle (2018), Glavinich (1995), Zimmerman and Hart (1982), Mohamed (2015) found the factors contributing to optimize the cost of construction are: replacing conventional materials with alternative materials, cost effective construction materials, low cost materials, local materials, the use of precast and prefabricated materials, good construction skills, proper building design and accurate estimate, well defined scope of work and clear specifications in contract agreement, proper planning, scheduling and management of construction, consider lowest possible detail while planning, to work activities simultaneously, to do work maximum with special and efficient equipment, proper and efficient use of available local resources, proper selection of suppliers, use of multi skilled labour, standardizing materials and purchasing procedures, application of constructability and value engineering in construction that is very similar to this study.

\section{Conclusions}

The study investigated the following major factors contributing to time overrun and cost overruns.

Time overrun factors: un-realistic contract duration of project, change in scope of work, cash flow and financial difficulties faced by contractors, delay in decision making for material approval, incomplete drawings and design at the time of tender, lack of coordination and communication between parties, delay in working drawings submitted by contractor for approval.

Cost overrun factors: delay caused by owner, quantity under estimation, design change or serious project design errors, price escalation, acceleration of project, change in legislation, inaccurate project estimate, lack of plan for change order, poor site management and incompetent project team.

Furthermore, the study revealed the major factors for optimization of construction costs are: clear scope and specifications of project, adequate details in drawings, timely procurement of imported materials, effective planning and scheduling of project by the contractor, use special and multi objective equipment, adequate quality control, simplicity of project design, accurate cost and time estimate, proper cash flow management, sufficient communication between owner 
and designer, and speed of information flow. The most important strategy to optimize the construction cost are effective cost planning and control, development of proper monitoring and tracking systems, sound working environment, recording daily work progress, using time cost trade off, following plan-do-check-act quality policy, hiring skilled labor and effective supervision. The study would like to suggest that constructability and value engineering principles should be adopted in all the major construction projects.

\section{References}

[1] Sabanna, Shivaraj, 2015. "Cost optimization in select consumer product sector companies in India", PHD thesis http://hdl.handle.net/10603/57248, Gulbarg University.

[2] Elbeltagi, E. 2009. Lecture Notes on Construction Project Management, Structural Engineering Department, Faculty of engineering, Mansoura University, Egypt.

[3] Khan, R. A. (2008), Role of Construction Sector in Economic Growth: Empirical Evidence from Pakistan Economy, conference paper, First International Conference on Construction In Developing Countries (ICCIDC-I)“Advancing and Integrating Construction Education, Research \& Practice" August 4-5, 2008, Karachi,, Pakistan, page 279-278.

[4] Baral, S, 2009 "Nepalese Construction Industry: Challenges “...santoshbaral.blogspot.com» 2009/12, Nepaleseconstruction-industry.

[5] Economic Survey 2017/18. Government of Nepal. Ministry of Finance. Singh Durbar, Kathmandu...Sep 14, 2018, page 10.

[6] FCAN, 2012. Construction Industry in Nepal. [Federation of Contractors association Nepal] Available at: http://www.fcan.org/np/pages.php?pid=83. [Last Accessed Jun 11-2016].

[7] KERZNER HAROLD, Ph. D, 2003, project Management, "A Systems Approach to Planning, Scheduling, and Controlling", EIGHTH EDITION, Division of Business Administration, Baldwin-Wallace College, Berea, Ohio.

[8] Chitrakar, M., 2005. Time overrun in Building Construction project in Nepal. MSc. Nepal Engineering College -CPS, Pokhara University.

[9] Basaula, P. R. (2015), "Time-Cost Optimization of Construction Operation: A case study on building construction project of CTEVT, Nepal", Master of Science in Engineering Managaement, Acme Engineering college, Purbanchal University, Nepal.

[10] Lester, A. (2000) Project Planning and Control, ButterworthHeinemann, Oxford.

[11] Nicholas, J. (2001) Project Management for Business and Technology, Prentice Hall, Upper Saddle River, NJ.

[12] Rajguru, Anuja, \& Mahatme, Parag. (March 2016) "Effective Techniques in Cost Optimization of Construction Project" International Journal of Research in Engineering and Technology Vol. 4, pp. 464-469.

[13] Sambasivan, M., \& Soon, Y. W. (2007), "Causes and effects of delays in Malaysian construction industry". International
Journal of Project Management, 25 (5), 517-526.

[14] Sah, Tumi, Omran, A., Pakir, AHK (2009), "Causes of delay in Construction Industry in Libya". Proc. Int. Conf. Administration and Business, Univ. Bucharest, Romania, 1415th November 2009. pp. 265-272.

[15] Mahadik U. A. (2015), "Cost Reduction in Construction Projects" www.ijetmas.com September 2015, Volume 3, Special Issue, ISSN 2349-4476, page-397.

[16] Savithra, M. N. and Amutha, M. (2019),"Cost Simulation in an Item Based Project Involving Construction Engineering and Management", www.ijirset.com Vol. 8, Issue 3, March 2019.

[17] NgS. \& Zhang Y. (2008), "Optimizing Construction Time \& Cost using Ant Colony Optimization Approach" Jr. Construction EM. (ASCE).

[18] Kashid P. M. \&Jamgade M. (2019), "Time and cost optimization of construction projects: A review”, ISSN: 22779655, http://www.ijesrt.com $\odot$ International Journal of Engineering Sciences \& Research Technology.

[19] Gomer, J. E., Hass, C. T. and Morton, D. P. (2002),"Assignment and Allocation Optimization of Partially Multi skilled Workforce". Journal of Construction Engineering and Management/March/April 2002, ASCE.

[20] Asamoah, R. O., Ankrah, J. S., Nyako, K. O. and Tutu, E. O. (2016), "Cost Analysis of Precast and Cast-in-Place Concrete Construction for Selected Public Buildings in Ghana" Hindawi Publishing Corporation Journal of Construction Engineering Volume 2016, Article ID 8785129.

[21] Rajguru, Anuja and Mahatme Parag (2015). "Effective techniques in cost optimization of construction project". IJIFR/ V3/ E5/ 03.

[22] Samuel, J. J. (2015)," Cost effective methods used in various levels of a building", International Journal of Engineering Research and General Science Volume 3, Issue 6, NovemberDecember, 2015, pp. 850-854.

[23] Mishra AK, Bhandari S. Performance Assessment of Ongoing Construction Projects under Town Development Fund, Nepal, Int j Adv Res Civil Stru Engr 2018; 1 (1\&2): 27-39.

[24] Maskey, Ajit and Mishra, A. K., 2018. "Labor productivity assessment of armed police force Nepal building construction projects", International Journal of Current Research, 10, (11), December, 2018.

[25] Chilwal K. and Mishra A. K., 2018. Impact of Performance on profitability of small hydropower projects in Nepal, International Journal of Current Research, 10 (1). pp. 63918 63925 .

[26] HEIZER, J.; RENDER, B. (1996) Production \& Operations Management: strategic and tactical decisions. 4th Edition. USA, New Jersey: Prentice Hall.

[27] TAMRAKAR, P. (2013) Analysis and Improvement by the Application of Network Analysis (Pert/CPM). The International Journal of Engineering and Science, v. 2, n. 1, pp. 154-159.

[28] Dania, A. A., Kehinde, J. O. and Bala, K. (2007),"A study of construction material waste manaagemet practices by construction firms in Nigeria", www.irb.fraunhofer.de. 
[29] Wan, Michele (2018)," Eight Key Strategies to Reduce Cost in the Construction Sector" PDPM. www.sipmm.org.sg.

[30]@easyprojects.net, 1120 Finch Avenue West, Suite 201, Toronto, Ontario, M3J 3H7 Canada.

[31] Glavinich, T. E., (1995), "Improving Constructability during Desihn phase", J. of Architectural Eng., Vol 1., No. 2, 73-76.

[32] Elsonosi, H. (2000)," Intelligent Computer System for Exchanging Value Engineering in the Egyptian Industry", AUC, p. 72; 2000.

[33] Zimmerman LW, and Hart GD.(1982)," Value Engineering, A Practical Approach for Owners, Designers and Contractors", Van Nostr and Reinhold Company, Inc., New York, 1982.
[34] Abidin N, Pasquire C. (2003) "Moving towards sustainability through value management. In: Proceedings of the joint international symposium of CIB working commissions W55, W65 and W107”, Singapore, Vol. 2, pp. 258-268; 2003.

[35] Mohamed, S. (2015), Integrating Value Engineering and Facility Management as an Approach to Face Risks, Master Thesis, Ain Shams University, Architecture Department (2015).

[36] Khodeir, L. M. and Ghandour, A. E., 2018, "Examining the role of value management in controlling cost overrun [application on residential construction projects in Egypt]" https://doi.org/10.1016/j.asej.2018.11.008.

[37] Rane, N. L., 2016, “Application of value engineering techniques in building construction projects", www.ijesrt.com. 